\title{
Characterization and developmental expression patterns of testicular androgen-binding protein in the Djungarian hamster (Phodopus sungorus)
}

\author{
J. M. Cates and D. A. Damassa* \\ Department of Anatomy and Cellular Biology, Tufts University Schools of Medicine, Dental Medicine, \\ Veterinary Medicine, and the Sackler School of Graduate Biomedical Sciences, 136 Harrison Avenue, \\ Boston, MA 02111, USA
}

\begin{abstract}
Studies were conducted to characterize Djungarian hamster androgen-binding protein and examine its expression during development. The cDNA encoding the full length testicular androgen-binding protein was cloned and, except for two suspected polymorphisms, shared a common primary sequence with hepatic sex hormone-binding globulin. A single androgenbinding protein/sex hormone-binding globulin gene was identified and a $1.7 \mathrm{~kb}$ mRNA encoding androgen-binding protein/sex hormone-binding globulin was present in both the testis and liver. Testicular homogenates contained specific $5 \alpha$-dihydrotestosterone-binding activity that was identified as androgen-binding protein. In the prepubertal testis, immunoreactive androgen-binding protein/sex hormone-binding globulin subunits ranged from $46 \mathrm{kDa}$ to $60 \mathrm{kDa}$, with the majority of isoforms $>50 \mathrm{kDa}$. These subunits were distinct from the major $55 \mathrm{kDa}$ and $51 \mathrm{kDa}$ isoforms of sex hormone-binding globulin present in the serum of prepubertal hamsters. Deglycosylation studies demonstrated that size heterogeneities were the result of developmentally specific glycosylation patterns. Expression of androgen-binding protein by the testis was upregulated during puberty and coincided with a decline in serum sex hormone-binding globulin activity. The tissue- and age-dependent expression of specific androgen-binding protein and sex hormone-binding globulin variants suggests that these proteins play different roles in steroid-mediated sexual development.
\end{abstract}

\section{Introduction}

Androgen-binding protein (ABP) is a glycoprotein produced by the Sertoli cells of the testis and secreted primarily into the lumen of the seminiferous tubule (Joseph, 1994). ABP binds certain androgens and oestrogens with high affinity and is internalized by spermatogenic and epididymal cells via specific receptors (Joseph, 1994; Gérard, 1995; Porto et al., 1995). A plasma protein with similar steroid-binding properties is produced by the liver and is commonly designated as sex hormone-binding globulin (SHBG) or sex steroid-binding protein. Both $A B P$ and SHBG are considered to be products of the same gene, but are glycosylated differently (Joseph, 1994). These proteins can influence sex steroid action by altering the uptake and metabolism of their ligands as well as by interacting directly with specific receptors on target cells (Rosner et al., 1992; Joseph, 1994; Gérard, 1995).

Significant changes in the expression of $\mathrm{ABP}$ and $\mathrm{SHBG}$ have been observed during important stages of reproductive development, such as the perinatal and pubertal periods (Damassa and Cates, 1995). In primates, serum SHBG activity increases shortly after birth in both males and females, and remains high until just before puberty (Chaussain et al., 1978;

*Correspondence.

Received 23 April 1997.
Forest et al., 1986; Westphal, 1986a). In contrast, testicular ABP concentrations are low during the perinatal period and increase during puberty (Westphal, 1986b; Keeping et al., 1990; Rey et al., 1993). Similar developmental patterns of ABP and SHBG expression have been observed in rabbits (Weddington et al., 1974; Berger et al., 1980; Westphal, 1986a, b). Unlike primates and rabbits, most rodent species (including rats, mice and golden hamsters) do not express SHBG after birth (Westphal, 1986a; Gustafson et al., 1989; Sullivan et al., 1991; Joseph, 1994). As in other species examined, ABP expression is upregulated during puberty in rats; however, the testicular concentration of ABP varies greatly from species to species (Carreau, 1986; Forest et al., 1986; Westphal, 1986b; Joseph, 1994). In rats, large amounts of ABP activity are measured during early puberty (Danzo and Eller, 1985; Westphal, 1986b; Joseph, 1994) whereas, in the mouse testis, $\mathrm{ABP}$ concentrations are much lower and detected only by sensitive immunological methods (Westphal, 1986b; Wang et al., 1989; Joseph, 1994).

The Djungarian hamster has become an important rodent model for the study of testicular development. Unlike other rodents, puberty and testicular activation can be delayed in hamsters exposed to short photoperiod (Hoffmann, 1978; Yellon and Goldman, 1984; Van Haaster et al., 1993). This species is also unique among rodents in expressing SHBG. As in primates, serum SHBG concentrations in both male and 
female hamsters increase markedly after birth and decrease at puberty (Gustafson et al., 1989; Cates et al., 1995). We have previously characterized SHBG in this species and observed age-related changes in SHBG glycosylation patterns (Cates et al., 1995). Such changes in glycosylation have been implicated in regulating the interactions of SHBG with the cellular SHBG-receptor (Avvakumov et al., 1988; Joseph, 1994). Despite the importance of the Djungarian hamster in the study of testicular development, little is known about the molecular structure and expression patterns of testicular ABP in this species. Therefore, Djungarian hamster ABP was cloned, characterized, and its molecular structure compared with those of other species. In addition, the developmental patterns of ABP expression and glycosylation were examined and compared with those of SHBG.

\section{Materials and Methods}

\section{Tissue and serum samples}

Djungarian hamsters (Phodopus sungorus) obtained from our breeding colony were housed as mating pairs and maintained on a long photoperiod ( $16 \mathrm{~h}$ light: $8 \mathrm{~h}$ dark); lights on at 06:00 h. Tissues and serum samples were collected from individual animals as described by Cates et al. (1995).

\section{Cloning of Diungarian hamster androgen-binding protein}

A pubertal testis ( 3 weeks of age) cDNA library was constructed in gt22A with the SuperScript Lambda System (GIBCO-BRL, Gaithersburg, MD) using RNA pooled from two hamsters. The library was screened using a 51-mer degenerate SHBG oligonucleotide based on the $\mathrm{N}$-terminal amino acid sequence of Djungarian hamster SHBG (Cates et al., 1995; Damassa et al., 1996). Ten positive plaques were isolated and rescreened; all isolates were true positives.

Individual resuspended plaques were used as templates for PCR amplification of cDNA inserts using gtII primers. All ten amplified cDNAs encoding ABP were approximately $1.4 \mathrm{~kb}$ in size. The products were then subcloned into pSV-SportI (GIBCO-BRL, Gaithersburg, MD), and both strands were sequenced as described by Cates et al. (1995). A consensus sequence of $C D N A$ encoding $A B P$ was constructed from the compilation of at least three independent sequencing reactions of six clones of $C D N A$ encoding $A B P$.

The longest cDNA encoding ABP was nearly full length, extending into the signal peptide coding region, and was designated PSV-ABP-5. The remaining coding sequence and the $5^{\prime}$ untranslated region (UTR) were cloned via $5^{\prime}$ rapid amplification of cDNA ends (5'RACE Kit, GIBCO-BRL, Gaithersburg, MD) of pubertal hamster testis polyadenylated RNA. Synthesis of testis cDNA was primed with a genespecific antisense oligonucleotide primer located 314-293 base pairs (bp) downstream from the $5^{\prime}$ end of pSV-ABP-5. After poly-dC tailing, the cDNA was amplified using a nested antisense gene-specific primer located 292-269 bp from the above reference point. The resulting 5 'RACE product was then cloned into pNoTA/T7 (5Prime-3Prime Inc., Boulder, CO). Six positive clones were isolated and sequenced as above.
Computer-based sequence assembly, as well as sequence similarity determinations and structural analyses, were made using the GCG software package (Genetics Computer Group, Inc., Madison, WI) and Entrez (NCBI, Bethesda, MD).

\section{Southern analysis}

Genomic DNA was isolated from Djungarian hamster liver (GNome DNA Isolation Kit, Ambion Inc., Austin, TX) and was subjected to Southern analysis (Ausubel et al, 1989). Restricted DNA (approximately $20 \mu \mathrm{g}$ ) was hybridized with a $1.2 \mathrm{~kb}$ partial Djungarian hamster CDNA encoding SHBG (Cates et al., 1995) labelled by random priming (DECAprime Random Priming DNA Labeling Kit, Ambion Inc., Austin, TX).

\section{Northern blotting}

RNA was isolated by guanidine thiocyanate-phenolchloroform extraction and subjected to northern analysis (30 $\mu \mathrm{g}$ total RNA) (Ausubel et al., 1989) using the $1.2 \mathrm{~kb}$ partial Djungarian hamster $\mathrm{CDNA}$ encoding SHBG as described by Cates et al. (1995). A complete developmental series was included on each blot. Densitometric analysis of ethidium bromide-stained 18S rRNA was used to normalize samples for differences in sample loading and transfer (see below).

\section{Steady-state native PAGE}

Samples were preincubated with $2.0 \mathrm{nmol}\left[{ }^{3} \mathrm{H}\right] 5 \alpha$ dihydrotestosterone (DHT) $\mathrm{I}^{-1}$ and fractionated by steadystate native PAGE as described by Gustafson et al. (1989). Nonspecific binding was assessed on duplicate gels containing 100-fold excess of cold DHT. To identify ABP, protein was eluted from gel slices containing DHT-binding activity, precipitated with $80 \%$ acetone and subjected to western analysis using an anti-SHBG/ABP peptide antiserum.

\section{Deglycosylation analysis}

Proteins in serum or testis homogenates $(50 \mu \mathrm{g})$ were precipitated with $80 \%$ acetone and resuspended in $10 \mu \mathrm{l}$ of digestion buffer $\left(50 \mathrm{mmol}\right.$ sodium phosphate $\mathrm{l}^{-1}$ (pH 7.5), $50 \mathrm{mmol} \beta$-mercaptoethanol $1^{-1}, 0.1 \%(\mathrm{w} / \mathrm{v}) \mathrm{SDS}$ ) and denatured at $100^{\circ} \mathrm{C}$ for $15 \mathrm{~min}$. After brief centrifugation at $12000 \mathrm{~g}$ for $10 \mathrm{~s}$ and cooling, $5 \mu \mathrm{l}$ of $7.5 \%$ Nonidet P-40 was added to the samples (to give a final concentration of $0.7 \%$ w/v). N-glycanase (6 U) (Genzyme Corp., Cambridge, MA) was then added to the samples and sterile water was used to bring the final volume to $25 \mu \mathrm{l}$. Reactions were carried out for $16 \mathrm{~h}$ at $37^{\circ} \mathrm{C}$. Duplicate samples were incubated without added $N$-glycanase. The reactions were terminated by acetone precipitation and samples were resuspended in $10 \mu \mathrm{l}$ of SDS buffer $\left(62 \mathrm{mmol}^{2}\right.$ Tris-HCl $\mathrm{l}^{-1}(\mathrm{pH} \mathrm{6.8)}, 0.1 \%$ SDS, $1.0 \%$ $\beta$-mercaptoethanol, $10 \%$ glycerol) in preparation for western blot analysis.

\section{Western blotting}

Western blots were performed as described by Cates et al. (1995) and Damassa et al. (1996). Samples of serum or testis 
homogenates containing $50 \mu \mathrm{g}$ protein were precipitated with $80 \%$ acetone and resuspended in SDS buffer for reducing SDS-PAGE. A previously characterized rabbit anti-SHBG peptide antisera (R2383-5) was used in immunoblot analyses (Cates et al., 1995; Damassa et al., 1996).

\section{Image analysis}

Measurements of the integrated optical density (IOD) of protein and RNA bands, as well as the determination of the relative molecular sizes of these bands, were made using computer-based image analysis (Biolmage Model 110S-2D system with Whole-Band Analysis software, Millipore, Bedford, MA).

\section{Statistical analysis}

Measurements of RNA encoding SHBG and SHBG immunoactivity are reported as means \pm SEM. Comparisons among means of the various age groups were made using Fisher's test and one-way analysis of variance (ANOVA). For statistical purposes, samples with undetectable activity were assigned values equal to the sensitivity limit of the appropriate assay. Differences were regarded as significant when $P<0.05$. All other studies were repeated at least twice.

\section{Results}

\section{Sequence analysis of Diungarian hamster androgen-binding protein}

A comparison of the deduced amino acid sequence of Djungarian hamster $\mathrm{ABP}$ with those obtained for other species is shown (Fig. 1). There is a high degree of sequence identity among the few species that have been studied (66-78\%). The Djungarian hamster cDNA encoding $\mathrm{ABP}$ contains an open reading frame of 1197 bases, which encodes a presumed leader peptide of 29 residues and the 370 amino acids of mature ABP (Fig. 1). The full length Djungarian hamster testicular clones of cDNA encoding $A B P$ differed at only two positions from a CDNA encoding SHBG previously isolated from Djungarian hamster liver by PCR cloning. Both nucleotide substitutions encode conservative amino acid changes (I-260 and V-295 in Djungarian hamster ABP are V-260 and G-295 in Djungarian hamster SHBG).

All four cysteine residues shown to participate in disulfide bonds in human SHBG are conserved in the hamster cDNA (Fig. 1). There are five potential sites of $\mathrm{N}$-glycosylation in hamster ABP. Two sites $(\mathrm{N}-241$ and $\mathrm{N}-364)$ are conserved across all species examined. The N-351 site in human SHBG/ $A B P$ is found in Djungarian hamster ABP at N-348, but not in other species. The remaining two potential $\mathrm{N}$-glycosylation sites (N-131 and N-324) appear to be unique to Djungarian hamster ABP. A potential O-glycosylation site is present in Djungarian hamster $\mathrm{ABP}(\mathrm{T}-5)$ and human $\mathrm{ABP}(\mathrm{T}-7)$, but not in rat or mouse $A B P$ (Fig. 1).

A single $1.7 \mathrm{~kb}$ mRNA encoding $A B P$, identical in size to the liver SHBG transcript, was identified in the pubertal testis by northern analysis (Fig. 2). Southern analysis of Djungarian hamster genomic DNA indicated that a single copy gene encodes both SHBG and ABP (Fig. 3). The entire SHBG/ABP gene is encoded within a $5.85 \mathrm{~kb}$ BamHl fragment and a $6.0 \mathrm{~kb}$ HindIII fragment. Digestion of Djungarian hamster genomic DNA with Sst results in two bands of 13.5 and $16.0 \mathrm{~kb}$, consistent with the one predicted SstI site in the hamster cDNA encoding $A B P$. Although there are two EcoRI digestion sites in the hamster cDNA encoding ABP, EcoRI digestion gives only two bands ( 9.0 and $1.4 \mathrm{~kb}$ ) owing to the proximity of the upstream site to the $5^{\prime}$ terminus of the cDNA probe.

\section{Identification of testicular androgen-binding protein}

Analysis of $\left[{ }^{3} \mathrm{H}\right] \mathrm{DHT}$-binding in adult testicular homogenates by 'steady-state' native PAGE revealed a single broad peak of specific activity with a slightly lower mobility than that of Djungarian hamster SHBG (Fig. 4). Addition of 100-fold molar excess of cold DHT eliminated the binding of $\left[{ }^{3} \mathrm{H}\right] \mathrm{DHT}$ to proteins within the low mobility peaks, but not to serum albumin (data not shown). The absence of $\left[{ }^{3} \mathrm{H}\right] \mathrm{DHT}$-binding by albumin in testicular homogenates suggests minimal plasma protein contamination.

When eluted from the native gel and separated by SDSPAGE, the peak of specific DH'T-binding activity in adult testicular homogenates migrated as a single $48 \mathrm{kDa}$ band that was recognized by a peptide antiserum generated against the common N-terminal 17 amino acids of Djungarian hamster SHBG/ABP. A similar predominant $48 \mathrm{kDa}$ band was also identified in immunoblots of adult testis homogenates (Fig. 5).

\section{Testicular androgen-binding protein isoforms}

Western blot analysis of testis protein from 1 week old hamsters revealed $55 \mathrm{kDa}$ and $51 \mathrm{kDa}$ isoforms, as well as minor $60 \mathrm{kDa}$ and $48 \mathrm{kDa}$ bands of immunoactivity (Fig. 5). The $55 \mathrm{kDa}$ and $51 \mathrm{kDa}$ isoforms are the same sizes as Djungarian hamster SHBG isoforms, but the relative abundances of these two isoforms were opposite to those found in hamster serum. After a transitional isoform pattern observed at 2 weeks of age, testicular ABP immunoactivity migrated as a major $48 \mathrm{kDa}$ band and minor 44 and $4 \mathrm{I} \mathrm{kDa}$ bands. As the hamsters age and enter adulthood ( 6 weeks), the intensity of immunostaining of all ABP isoforms decreased (Fig. 5). Control blots using preimmune serum instead of the anti-SHBG serum were consistently negative (data not shown).

\section{Deglycosylation of androgen-binding protein}

The contribution of differential glycosylation to the electrophoretic microheterogeneity observed among Djungarian hamster SHBG/ABP isoforms was examined by digestion of the proteins with $\mathrm{N}$-glycanase. The 55 and $51 \mathrm{kDa}$ isoforms of serum $\mathrm{SHBG}$, the $48 \mathrm{kDa} \mathrm{ABP}$ isoform in pubertal testes, and the heterogeneous isoforms of $A B P$ observed in prepubertal hamster testes were all converted into a major immunoreactive band of $44 \mathrm{kDa}$ (Fig. 5). A minor band of $41 \mathrm{kDa}$ was also observed in $\mathrm{N}$-glycanase-digested testicular homogenates, but not in serum that had been similarly treated. 


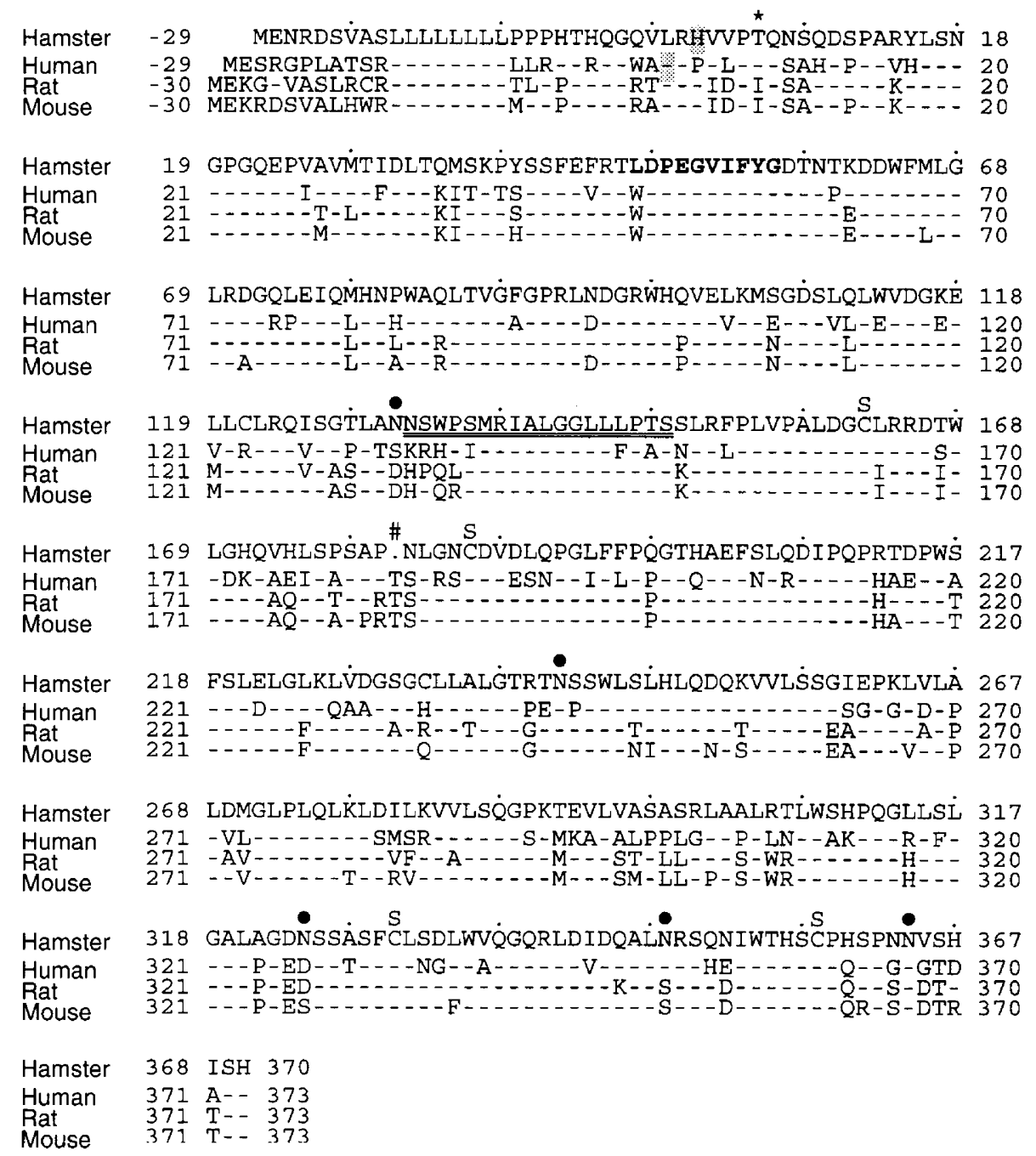

Fig. 1. Sequence comparison of Djungarian hamster androgen-binding protein $(A B P)$ with those of other species. The deduced amino acid sequence of Djungarian hamster $A B P$ is compared with human sex hormone-binding globulin (SHBG)/ABP (Walsh et al., 1986; Gershagen et al., 1987a) and the predicted sequences derived from the rat (Joseph, 1994) and mouse (Wang et al., 1989) cDNAs encoding ABP. The rabbit SHBG sequence is not included since it is only partial length (Griffin et al., 1989) and there are some sequence discrepancies (Wang et al., 1989). Numbers refer to the position in relation to the first amino acid of mature SHBG (O) determined by direct amino acid sequencing (Damassa et al., 1996). The putative SHBG-receptor binding site (Khan et al., 1990) is marked in bold type and the steroid-binding region (Joseph, 1994) is double-underlined. S, conserved cysteine residues participating in disulfide bonds in human and rat SHBG; 0 , potential $N$-linked glycosylation sites; ${ }^{*}$, potential O-linked glycosylation site (Joseph, 1994; Walsh et al., 1986); \#, deleted residue in hamster ABP.

Developmental patterns of testicular expression of androgen-binding protein and serum sex hormone-binding protein

Neonatal hamster testes were too small to analyse individually; however, mRNA encoding $\mathrm{ABP}$ was detected at all other ages examined. Transcript concentrations were low $(40-60 \%$ of maximum concentrations) in 1 and 2 week old hamsters, but peaked at 3 weeks of age (Fig. 6). The amount of message decreased to $40 \%$ and $20 \%$ of peak concentrations by 4 and 6 weeks of age, respectively.

The predominant $48 \mathrm{kDa}$ immunoactive isoform of $\mathrm{ABP}$ was expressed at very low concentrations in the testis until 3 weeks of age, when concentrations increased significantly (Fig. 6). Testicular concentrations of the $48 \mathrm{kDa}$ isoform in late pubertal-early adult hamsters ( 6 weeks of age) were significantly lower than the peak values observed in mid-pubertal (4-5 weeks of age) males (Fig. 6). Owing to the greater contribution of heavier SHBG-like isoforms in the prepubertal testis, the amount of total $A B P$ immunoactivity (the sum of the IODs of all detected isoforms) remained relatively constant from 1 week until 4 weeks of age (data not shown).

In serum, immunoactive SHBG/ABP isoforms were detected in males and females throughout prepubertal development (Fig. 7). The previously identified 55 and $51 \mathrm{kDa}$ SHBG isoforms 


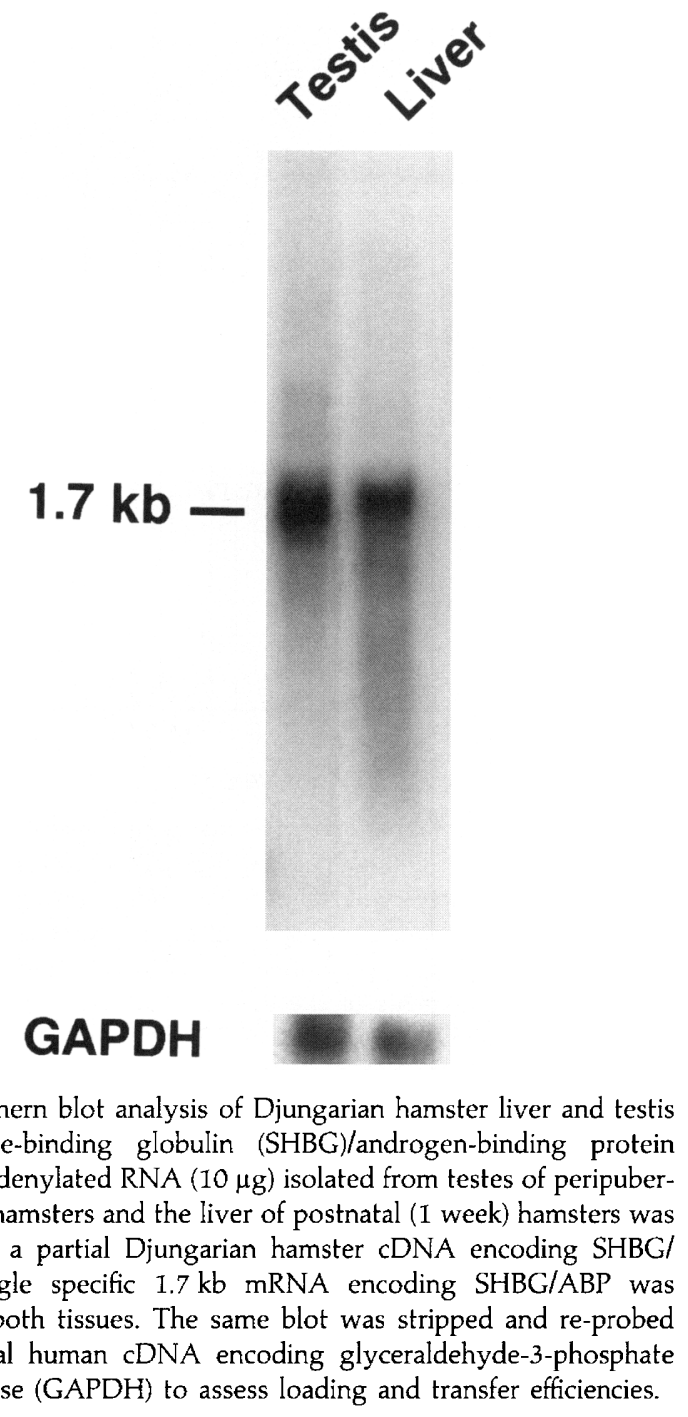

were present at high concentrations from birth until 2 weeks of age in all animals. During this postnatal period, trace amounts of 48 and $44 \mathrm{kDa}$ isoforms were also found in serum of both males and females, indicating that the testes were not the source of the immunoactivity. After 2 weeks of age, there was an overall decrease in all SHBG/ABP isoforms in serum from both sexes (Fig. 7).

\section{Discussion}

Djungarian hamster $\mathrm{ABP}$ and SHBG were found to be products of a single gene, as has been shown for human and rat ABP/SHBG (Gershagen et al., 1989; Sullivan et al., 1991; Joseph, 1994). The two nucleotide differences in the testis clones of cDNA encoding $\mathrm{ABP}$ relative to that reported for a Djungarian hamster liver clone of $\mathrm{CDNA}$ encoding SHBG could reflect polymorphism in the hamster gene pool or PCR-cloning artifacts (Cates et al., 1995). The conservative amino acid differences predicted by the two discrepancies between the ABP and SHBG CDNAs suggest that these
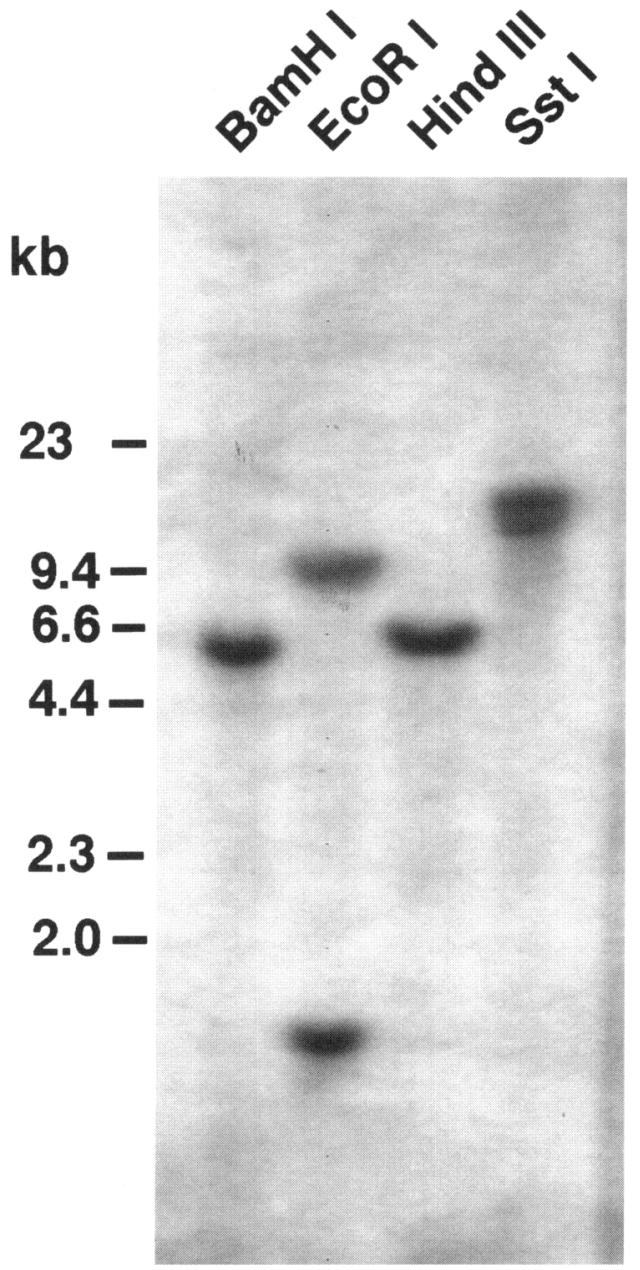

Fig. 3. Southern blot analysis of Djungarian hamster genomic DNA. Djungarian hamster genomic DNA $(15 \mu \mathrm{g})$ was restricted with the indicated enzymes and probed with a partial Djungarian hamster cDNA encoding sex hormone-binding globulin (SHBG)/androgenbinding protein (ABP). The positions of $\lambda$-Hind III digested DNA markers are shown on the left.

are polymorphisms, with at least two alleles encoding Djungarian hamster SHBG/ABP. Genetic variants of SHBG have also been observed in humans (Gershagen et al., 1987b; Power et al., 1992; Joseph, 1994; Larrea et al., 1995; Hardy et al., 1995).

The overall homology of Djungarian hamster SHBG/ABP with that of other mammals is high $(66-78 \%)$. Long stretches of extensive identity interspersed with short regions of divergent sequence are particularly notable upon comparison of the aligned sequences of several species. This high degree of conservation may indicate regions with strict secondary structure that are critical for SHBG/ABP function (such as dimerization, steroid binding, and recognition of cell surface receptors) flanked by less conserved, possibly species-specific, structural regions (Khan et al., 1990; Joseph, 1994; Hammond and Bocchinfuso, 1995).

The major isoform of $\mathrm{ABP}$ in the mature hamster testis is $48 \mathrm{kDa}$, in contrast to the principal 55 and $51 \mathrm{kDa}$ variants of serum SHBG. Differences in the molecular weights of $A B P$ and 


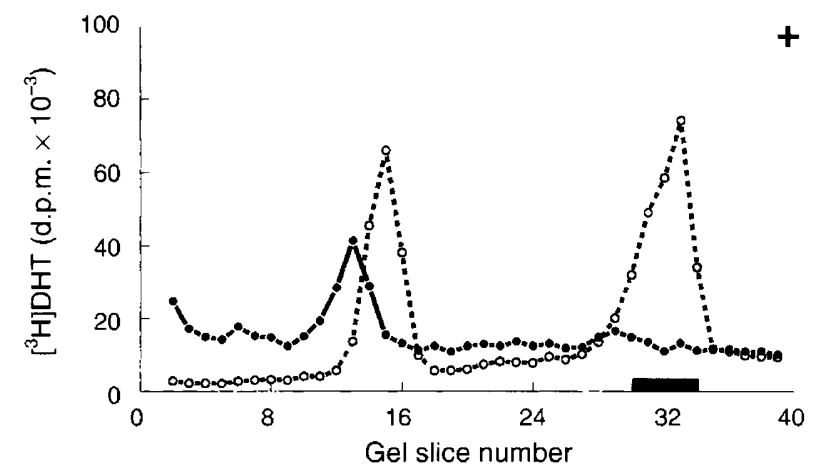

Fig. 4. 'Steady-state' PAGE of testicular homogenates and serum from Djungarian hamsters. Serum of 2 week-old female hamsters $(O)$ and homogenates of adult hamster testes $(0)$ were preincubated with $2.0 \mathrm{nmol}\left[{ }^{3} \mathrm{H}\right] 5 \alpha$-dihydrotestosterone (DHT) $\mathrm{I}^{-1}$ and then separated on native acrylamide gels containing $1.0 \mathrm{nmol}\left[{ }^{3} \mathrm{H}\right] \mathrm{DHT} \mathrm{l}^{-1}$. The d.p.m. of $\left[{ }^{3} \mathrm{H}\right] \mathrm{DHT}$ in each gel slice is plotted against gel slice number (beginning at the origin). $\mathbf{a}$, Position of serum albumin, determined by staining gel slices with bromcresyl green.

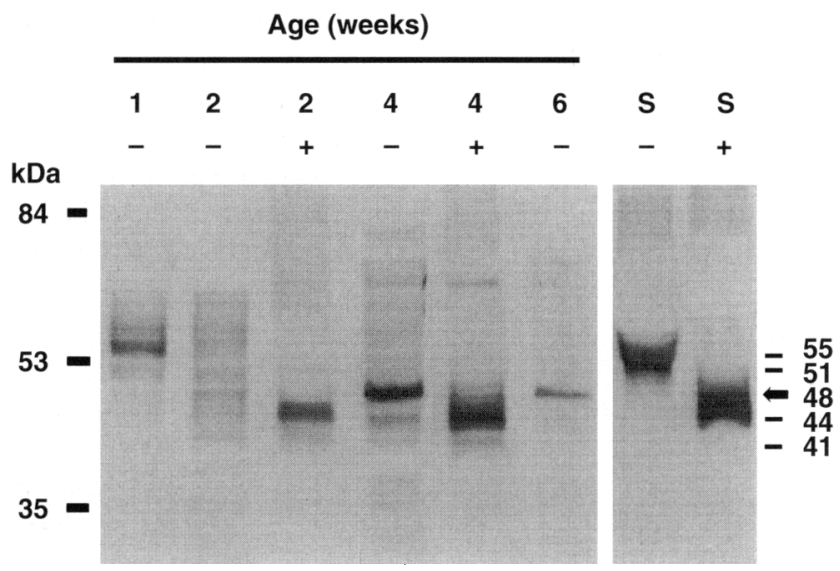

Fig. 5. Western blot analysis of Djungarian hamster sex hormonebinding globulin (SHBG)/androgen-binding protein (ABP) and effects of deglycosylation. Testis homogenates from hamsters aged I, 2, 4, and 6 weeks of age and serum from 2 week old female hamsters (S) were separated by SDS-PAGE. Selected samples were treated with $N$-glycanase $(+)$ or with the reaction buffer only $(-)$. The antiSHBG/ABP peptide antisera recognized multiple molecular weight isoforms of $\mathrm{ABP}$ in prepubertal testis, including the serum SHBG-like 55 and $51 \mathrm{kDa}$ isoforms. A $48 \mathrm{kDa}$ immunoreactive protein (large arrow) became the predominant $\mathrm{ABP}$ isoform as males reached puberty ( 4 weeks) and older ( 6 weeks). Removal of $N$-linked carbohydrates from ABP of prepubertal and pubertal testis and from SHBG of postnatal female serum resulted in a major $44 \mathrm{kDa}$ immunoactive species. The mobilities of the molecular mass standards $(\mathrm{kDa})$ are shown on the left and computer-determined molecular weight estimates for the predominant isoforms are shown on the right.

SHBG isoforms have also been reported in other species. In adult rabbits, as in Djungarian hamsters, the predominant serum SHBG isoform is larger than testicular ABP (Westphal, 1986a, b; Joseph, 1994); in contrast, the human ABP variants $(54 \mathrm{kDa}$ and $50 \mathrm{kDa}$ ) are larger than those of human SHBG (52 kDa and $48 \mathrm{kDa}$ ) (Westphal, 1986b; Joseph, 1994).

Variable degrees of glycosylation appear to account for the differences observed in the relative molecular weights of the

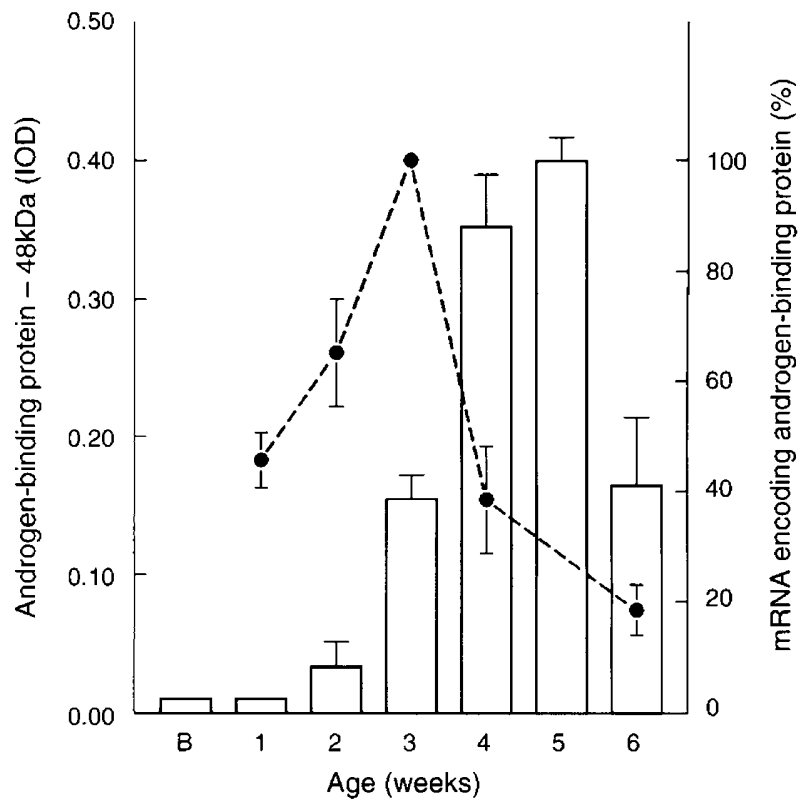

Fig. 6. Developmental patterns of testicular androgen-binding protein (ABP) expression in Djungarian hamsters. Data are presented as the percentage of the density (IOD) of the hybridization signal relative to that measured at 3 weeks of age (100\%) of mRNA encoding ABP, after normalization to the amount of $18 \mathrm{~S}$ rRNA transferred to the filter (1). Measurements of the IOD of immunoblots of the major $\mathrm{ABP}$ isoform $(48 \mathrm{kDa})$ were made using computerized image analysis $(\square)$. Data are expressed as means \pm SEM; $n=3-6$ animals per age group. B, birth.

SHBG/ABP subunits in Djungarian hamsters, as has been shown for other species (Danzo et al., 1991; Petra et al., 1992; Joseph, 1994). The predicted core molecular weight of Djungarian hamster SHBG/ABP based on the deduced amino acid sequence is $40.6 \mathrm{kDa}$. Therefore, the minor $41 \mathrm{kDa}$ isoform produced by $\mathrm{N}$-glycanase treatment of testicular extracts probably represents completely deglycosylated ABP, whereas the major $44 \mathrm{kDa}$ isoform indicates the presence of an O-linked glycan on ABP (presumably at T-5, analogous to T-7 in human SHBG) (Walsh et al., 1986; Joseph, 1994). In general, ABP isoforms in the immature testis are larger than those found in the adult testis. In particular, ABP isoforms in early postnatal testes appear to resemble those of serum SHBG. The SHBGlike immunoactivity in the neonatal testis is not due to gross plasma contamination since $\left[{ }^{3} \mathrm{H}\right] \mathrm{DHT}$-binding activity attributable to serum albumin was not detectable in testicular extracts. In addition, the ratio of the 55 and $51 \mathrm{kDa}$ molecular weight isoforms was different in testicular extracts compared with serum. Since testicular ABP transcripts are detected at these ages, the immature Sertoli cells may be glycosylating $\mathrm{ABP}$ in 'SHBG-like' patterns (Cheng et al., 1986; Danzo et al., 1991; Joseph, 1994). Alternatively, the testis may selectively sequester certain SHBG isoforms during the early postnatal period (Larrea et al., 1981; Sakiyama et al., 1988; Gérard et al., 1994). Thus, an exogenous source of the testicular SHBG-like isoforms cannot be ruled out, and further investigation is necessary to clarify the origin of ABP immunoactivity in the neonatal testis.

Whereas the extent of glycosylation of SHBG in liver and serum increases during early postnatal development, the 


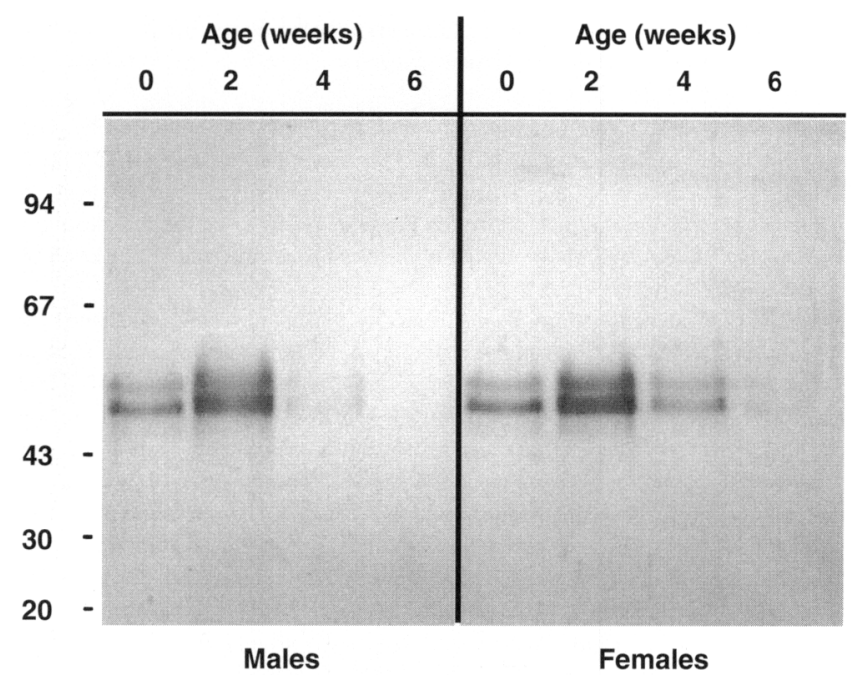

Fig. 7. Western blot analysis of Djungarian hamster serum sex hormone-binding globulin (SHBG) in males and females during development. Serum (1.0 $\mu$ l) from male or female hamsters aged 0 (I day), 2, 4, and 6 weeks of age were separated by SDS-PAGE. Anti-SHBG/androgen-binding protein (ABP) antisera recognized the major $55 \mathrm{kDa}$ and $51 \mathrm{kDa}$ isoforms in animals up to 4 weeks of age. Minor $48 \mathrm{kDa}$ and $41 \mathrm{kDa}$ bands were seen in sera from both males and females at 2 weeks of age or younger. The mobilities of the molecular weight standards $(\mathrm{kDa})$ are shown on the left.

number and size of oligosaccharides on $\mathrm{ABP}$ decreases during the same period. Thus, it appears that both the testis and liver of Djungarian hamsters are capable of generating similar molecular weight isoforms of ABP and SHBG, but that these processes are independently regulated and follow agedependent patterns in each tissue. The significance of shifting isoform ratios is unclear. Differential glycosylation does not appear to influence the steroid-binding properties of SHBG (Bocchinfuso et al., 1991; Petra et al., 1992; Joseph, 1994), but may affect the interaction of SHBG with steroid-responsive cells (Avvakumov et al, 1988; Rosner et al., 1992; Joseph, 1994; Damassa and Cates, 1995; Porto et al., 1995; Gérard, 1995) or target specific isoforms to different secretory pathways (Cheng et al., 1986; Danzo et al., 1991; Joseph, 1994). Analysis of glycosylation variants by differences of molecular weight measured by PAGE is rather crude, and the nature and number of glycans added to Djungarian hamster SHBG and ABP are unknown. Determining what differences in glycosylation are responsible for the generation of different molecular weight variants of $A B P$ and $S H B G$ would require a more detailed analysis of specific isoforms. However, on the basis of ratios of the relative abundance of the major $44 \mathrm{kDa}$ isoform to the minor $41 \mathrm{kDa}$ isoform of $\mathrm{ABP}$ and $\mathrm{SHBG}$ subjected to $\mathrm{N}$-deglycosylation, it may be surmised that the vast majority of both these proteins are glycosylated via an $O$-linkage, similar to human SHBG (Walsh et al., 1986; Joseph, 1994).

In Djungarian hamsters, $A B P$ expression is minimal during early postnatal development. Conversely, hepatic expression of serum SHBG peaks at this time. ABP message concentrations peak early in puberty (at 3 weeks of age); the reduction in concentrations of $\mathrm{ABP}$ and mRNA encoding $\mathrm{ABP}$ that occur thereafter may be due either to hormonal insensitivity of mature Sertoli cells or to dilution of Sertoli cell products by an increasing germ cell mass during puberty (Hall et al., 1990). Testicular ABP concentrations increase at puberty but there is a coincident decrease in hepatic SHBG expression and circulating androgen-binding activity. Similar patterns have been observed in pubertal monkeys and rabbits (Weddington et al., 1974; Berger et al., 1980; Forest et al., 1986; Westphal, 1986a, b; Keeping et al., 1990). Although other rodents also upregulate $A B P$ at puberty, they do not exhibit the postnatal surge in hepatic SHBG expression observed in Djungarian hamsters (Weddington et al., 1974; Berger et al., 1980; Westphal, 1986b; Keeping et al., 1987; Gustafson et al., 1989; Cates et al., 1995).

The reasons for species differences in $A B P$ and $S H B G$ expression and their implications regarding the actions of these proteins are unknown, but may be related to the development and maturation of spermatozoa and other steroid target tissues. Djungarian hamsters raised under a long photoperiod ( $18 \mathrm{~h}$ light: $6 \mathrm{~h}$ dark) normally enter puberty shortly after birth, at around 3 weeks of age (Van Haaster et al., 1993). However, when they are raised under a short photoperiod $(6 \mathrm{~h}$ light: $18 \mathrm{~h}$ dark), puberty is delayed for up to a year (Hoffmann, 1978; Yellon and Goldman, 1984; Van Haaster et al., 1993). In contrast, rodent species that lack postnatal increases in SHBG, such as mice, rats and golden hamsters, show a rapid onset of puberty even when raised under a short photoperiod. Whether SHBG, acting through its receptor, influences the timing of the maturational increases in FSH or the activation of steroid sensitive tissues in Djungarian hamsters remains to be determined.

Rao et al. (1995) have reported that male Djungarian hamsters exposed to a short photoperiod from birth upregulated testicular $\mathrm{ABP}$ expression at the appropriate postnatal age and continued to express high concentrations of mRNA encoding $A B P$ beyond 3 weeks of age. In contrast, concentrations of mRNA encoding $A B P$ in hamsters reared under a long photoperiod decreased at puberty. How these differences in concentrations of mRNA encoding $\mathrm{ABP}$ are related to changes in the cellular composition of the testis or to $\mathrm{ABP}$ protein production is not known. Therefore, it is difficult to postulate relationships between $\mathrm{ABP}$ and short photoperiodinduced delay of testicular development. Further study of the physiological consequences of species-specific differences in the expression and glycosylation of testicular $\mathrm{ABP}$ and hepatic SHBG throughout development are needed to characterize the role of these proteins in modulating steroid action at target tissues.

The authors thank G. Gagin and J. Schindler for technical assistance. Supported by the Tufts University NICHD Center for Reproductive Research ( HD28897) and the NIH (HD16535). Sequence data submitted to Genbank Accession Number (U63010).

\section{References}

Ausubel FM, Brent R, Kingston RE, Moore DD, Seidman JG, Smith JA and Struhl K (1989) Current Protocols in Molecular Biology Greene Publishing Associates and Wiley Interscience, New York

Avvakumov GV, Zhuk NI and Strel'chenok OA (1988) Biological function of the carbohydrate component of human sex hormone-binding globulin Biokhimiia $53 \quad 838-841$ 
Berger M, Corre M, Jean-Faucher C, De Turckheim M, Veyssiere G and Jean C (1980) Age related changes in percent binding of testosterone and dihydrotestosterone and unbound testosterone and dihydrotestosterone in rabbit plasma Journal of Steroid Biochemistry 13 423-429

Bocchinfuso WP, Warmels-Rodenhiser S and Hammond GL (1991) Expression and differential glycosylation of human sex hormone-binding globulin by mammalian cell lines Molecular Endocrinology 5 1723-1729

Carreau S (1986) L'“androgen binding protein" (ABP) chez le rat, le bélier, le taureau et l'homme: analyse comparée Colloque INSERM 149 293-303

Cates JM, Damassa DA, Gagin GA and Dempsey RV (1995) Hepatic expression of sex hormone-binding globulin associated with the postnatal surge of serum androgen-binding activity in the Diungarian hamster Journal of Steroid Biochemistry and Molecular Biology 55 147-158

Chaussain JJ, Brijawi A, Georges P, Roger M, Donnadieu M and Job JC (1978) Variations of serum testosterone estradiol binding globulin (TeBG) binding capacity in infants during the first year of life Actu Paediatrica Scandinavica 67 649653

Cheng CY, Gunsalus GL, Morris ID, Turner TT and Bardin CW (1986) The heterogeneity of rat androgen binding protein ( $\mathrm{AABP}$ ) in the vascular compartment differs from that in the testicular tubular lumen - further evidence for bidirectional secretion of rABP Journal of Andrology 7 175179

Damassa DA and Cates JM (1995) Sex hormone-binding globulin and male sexual development Neuroscience and Biobehavioral Reviews 19 165-175

Damassa DA, Gagin GA and Gustafson AW (1996) Purification and characterization of the sex hormone-binding globulin in serum from Djungarian hamsters Comparative Biochemistry and Physiology [B] 113 593-599

Danzo BJ and Eller BC (1985) The ontogeny of biologically active androgenbinding protein in rat plasma, testis, and epididymis Endocrinology 117 $1380-1388$

Danzo BJ, Black JH and Bell BW (1991) Analysis of the oligosaccharides on androgen-binding proteins: implications concerning their role in structure/ function relationships Journal of Steroid Biochemistry and Molecular Biology 40 821-831

Forest MG, Bonneton A, Lecoq A, Brébant $C$ and Pugeat $M$ (1986) Ontogenèse de la protéine de liaison des hormones sexuelles (SBP) et de la transcortine (CBG) chez les primates: variations physiologiques et étude dans différents milieux biologiques Colloque INSERM 149 263-291

Gérard A (1995) Endocytosis of androgen-binding protein (ABP) by spermatogenic cells Journal of Steroid Biochemistry and Molecular Biology 53 533-542

Gérard H, Gérard A, En Nya A, Felden F and Guéant JL (1994) Spermatogenic cells do internalize Sertoli androgen-binding protein: a transmission electron microscopy autoradiographic study in the rat Endocrinclogy $\mathbf{1 3 4}$ $1515-1527$

Gershagen S, Fernlund P and Lundwall $\AA$ (1987a) A cDNA coding for human sex hormone binding globulin: homology to vitamin K-dependent protein $S$ FEBS Letters 220129

Gershagen S, Henningsson K and Fernlund P (1987b) Subunits of human sex hormone binding globulin. Interindividual variation in size Journal of Biological Chemistry 262 8430-8437

Gershagen S, Lundwall $\dot{A}$ and Fernlund P (1989) Characterization of the human sex hormone binding globulin (SHBG) gene and demonstration of two transcripts in both liver and testis Nucleic Acids Research 17 9245-9258

Griffin PR, Kumar S, Shabanowitz J, Charbonneau H, Namkung PC, Walsh KA, Hunt DF and Petra PH (1989) The amino acid sequence of the sex steroid-binding protein of rabbit serum Journal of Biological Chemistry $\mathbf{2 6 4}$ $19066-19075$

Gustafson AW, Damassa DA, Pratt RD and Kwiecinski GG (1989) Postnatal patterns of plasma androgen-binding activity in Djungarian (Phodopus sungorus) and golden (Mesocricetus auratus) hamsters Journal of Reproduction and Fertility 86 91-104

Hall SH, Conti M, French FS and Joseph DR (1990) Follicle-stimulating hormone regulation of androgen-binding protein messenger RNA in Sertoli cell cultures Molecular Endocrinology 4 349-355

Hammond GL and Bocchinfuso WP (1995) Sex hormone-binding globulin/ androgen-binding protein: steroid-binding and dimerization domains Journal of Steroid Biochemistry and Molecular Biology 53 543-552

Hardy DO, Cariño C, Catterall JF and Larrea F (1995) Molecular characterization of a genetic variant of the steroid hormone-binding globulin gene in heterozygous subjects Journal of Clinical Endocrinology and Metabolism 80 1253-1256
Hoffmann K (1978) Effects of short photoperiods on puberty, growth, moult in the Djungarian hamster (Phodopus sungorus) Journal of Reproduction and Fertility $\mathbf{5 4} 29-35$

Joseph DR (1994) Structure, function, and regulation of androgen-binding protein/sex hormone-binding globulin Vitamins and Hormones 49 197-280

Keeping HS, Winters SJ and Troen P (1987) Age-dependent differences in testicular and epididymal androgen-binding protein in the cynomolgus monkey, Macaca fascicularis. Annals of the New York Academy of Sciences $\mathbf{5 1 3}$ 455-457

Keeping HS, Winters SJ, Attardi B and Troen P (1990) Developmental changes in testicular inhibin and androgen-binding protein during sexual maturation in the cynomolgus monkey, Macaca fascicularis. Endocrinology 126 2858-2867

Khan MS, Hryb DJ, Hashim GA, Romas NA and Rosner W (1990) Delineation and synthesis of the membrane receptor-binding domain of sex hormonebinding globulin Journal of Biological Chemistry 26518 362-18 365

Larrea F, Musto N, Gunsalus G and Bardin CW (1981) The microheterogeneity of rat androgen-binding protein from the testis, rete testis fluid, and epididymis, as demonstrated by immunoelectrophoresis and photoaffinity labeling Endocrinology 109 1212-1220

Larrea F, Cariño C, Hardy DO, Musto NA and Catterall JF (1995) Genetic variations in human testosterone-estradiol binding globulin Journal of Steroid Biochemistry and Molecular Biology 53 553-559

Petra PH, Griffin PR, Yates JR,III, Moore K and Zhang W (1992) Complete enzymatic deglycosylation of native sex steroid-binding protein (SBP or SHBG) of human and rabbit plasma: effect on the steroid-binding activity Protein Science 1 902-909

Porto CS, Lazari MFM, Abreu LC, Bardin CW and Gunsalus GL (1995) Receptors for androgen-binding proteins: internalization and intracellular signalling Journal of Steroid Biochemistry and Molecular Biology 53 561-565

Power SGA, Bocchinfuso WP, Pallesen M, Warmels-Rodenhiser S, Van Baelen $\mathrm{H}$ and Hammond GL (1992) Molecular analyses of a human sex hormonebinding globulin variant: evidence for an additional carbohydrate chain Journal of Clinical Endocrinology and Metabolism 75 1066-1070

Rao JN, Chandrashekar V, Borg KE and Bartke A (1995) Effects of photoperiod on testicular inhibin- $\alpha$ and androgen-binding protein mR.VA expression during postnatal development in Siberian hamsters, Phodopus sungorus. Life Sciences 57 1761-1770

Rey RA, Campo SM, Bedecarrás P, Nagle CA and Chemes HE (1993) Is infancy a quiescent period of testicular development? Histological, morphometric, and functional study of the seminiferous tubules of the cebus monkey from birth to the end of puberty Journal of Clinical Endocrinology and Metabolism 76 $1325-1331$

Rosner W, Hryb DJ, Khan MS, Nakhla AM and Romas NA (1992) Sex hormonebinding globulin: binding to cell membranes and generation of a second messenger Journal of Andrology 13 101-106

Sakiyama R, Pardridge WM and Musto NA (1988) Influx of testosterone-binding globulin (TeBG) and TeBG-bound sex steroid hormones into rat testis and prostate Journal of Clinical Endocrinology and Metabolism 67 98-103

Sullivan PM, Petrusz P, Szpirer C and Joseph DR (1991) Alternative processing of androgen-binding protein RNA transcripts in fetal rat liver. Identification of a transcript formed by trans splicing Journal of Biological Chemistry 266 143-154

Van Haaster LH, Van Eerdenburg FJCM and De Rooij DG (1993) Effect of prenatal and postnatal photoperiod on spermatogenic development in the Djungarian hamster (Phodopus sungorus sungorus) Journal of Reproduction and Fertility 97 223-232

Walsh KA, Titani K, Takio K, Kumar S, Hayes R and Petra PH (1986) Amino acid sequence of the sex steroid binding protein of human blood plasma Biochemistry 25 7584-7590

Wang Y-M, Sullivan PM, Petrusz. P, Yarbrough W and Joseph DR (1989) The androgen-binding protein gene is expressed in CD1 mouse testis Molecular and Cellular Endocrinology 63 85-92

Weddington SC, McLean WS, Nayfeh SN and French FS (1974) Androgen binding protein (ABP) in rabbit testis and epididymis Steroids 24 123-134

Westphal U (1986a) Sex steroid-binding protein (SBP) Monographs on Endocrinology 27 198-275

Westphal U (1986b) Androgen-binding protein (ABP) Monographs on Endocrinology 27 276-301

Yellon SM and Goldman BD (1984) Photoperiod control of reproductive development in the male Djungarian hamster (Phodopus sungorus) Endocrinology 114 664-670 